\title{
Peter Canisius and the Protestants
}

\section{A Model of Ecumenical Dialogue?}

\author{
Hilmar M. Pabel
}

Department of History, Simon Fraser University,

Burnaby, British Columbia, Canada

pabel@sfu.ca

\begin{abstract}
Some modern interpreters have incorrectly suggested that Peter Canisius was an ecumenist before his time. Their insistence on his extraordinary kindness towards Protestants does not stand the test of the scrutiny of the relevant sources. An analysis of Canisius's advice on how Jesuits should deal with "heretics" in Germany, of his catechisms, and of his polemical works reveals a typical Catholic controversialist of the Reformation era. Canisius was disposed to display hostility, more than good will, to Protestants.
\end{abstract}

\section{Keywords}

Peter Canisius - Protestants - Reformation - apologetics

\section{Introduction: The Celebration of a Saint}

Peter Canisius's path to canonization was a long one. He died in 1597. The formal ecclesiastical process to declare him a saint began in 1625 , but his beatification, solemnly pronounced by Pope Pius IX, had to wait until $1864 .{ }^{1}$ In Militantis ecclesiae (1897), Pope Leo XIII marked the 3ooth anniversary of Canisius's death by hailing him as "the second apostle of Germany." St. Boniface, the eighthcentury Anglo-Saxon missionary, was the first. Pius XI not only canonized Canisius in 1925; he also declared him a doctor of the universal church. ${ }^{2}$ This

1 Forian Rieß, Der selige Petrus Canisius aus der Gesellschaft Jesu (Freiburg im Breisgau: Herder, 1865), 552, 554 .

2 Otto Braunsberger, “Sanctus Petrus Canisius Doctor Ecclesiae," Gregorianum 6 (1925): 338. 
was a rare distinction, as Yves de la Brière reported two weeks later in the Jesuit journal Études. In so honoring "Saint Peter Canisius, Jesuit, apostle of the Counter-Reformation in Germany," the pope bestowed upon him a "glorious title" that since the twelfth century had been accorded only to Saints Bernard of Clairvaux, Thomas Aquinas, Bonaventure, Francis de Sales, and Alfonso Ligouri. ${ }^{3}$

Prominent among the papal representations is Canisius the combative champion of Catholic orthodoxy and correlatively the resolute foe of heresy. In his breve of beatification (1864), Pius IX wrote that Canisius, under the leadership of Ignatius of Loyola, emerged to "fight eagerly and bravely against the new kind of enemies." He did so in "the especially disastrous age of Luther." Insults, threats, and even the endangerment of his life could not deter Canisius from committing his mental and physical strength to the support of religion, "which was suffering tremendously as a result of the treacherous cunning of the Protestants."4 In 1897, Leo XIII hailed Canisius as a defender of Catholic youth from a "twofold plague" that arose when a "massive loss of faith and a perversion of morals" gave rise to an "enthusiasm for revolution and the way of unrestrained teaching." The pope offered "in full view the example of the restless leader Peter Canisius for those who fight for Christ in the armed forces of the Church." In his sermon at the canonization ceremony, Pius XI pointed out that by virtue of his impressive theological learning it was no surprise that Canisius "marched down into battle as a highly armed soldier in order to attack the monstrous errors of the heretics." In the longer decree justifying Canisius's sainthood and title of doctor of the church, the pope prominently hailed him as "a hammer of heretics." 6

Three months after the canonization, a short essay entitled "Canisius und die Protestanten" appeared as the final contribution to the August 1925 issue of the German Jesuit journal Stimmen der Zeit. The author, Max Pribilla, S.J. observed that as a result of the canonization of Canisius, "a champion of the Counter-Reformation," one could notice in the German Protestant press "an unmistakable discontent that found expression now in a sincere concern for the continuation of confessional peace, now in a fierce irritability or even in spite." Even "conciliatory-minded Protestants" viewed "the Roman celebration" as "a terrible embarrassment." Was Rome engineering a "new CounterReformation" by making Canisius the patron of a "Catholic offensive" and

3 Études 183 no. 11 (June 5, 1925): 619-20.

4 The breve is printed as an appendix to Rieß, Der selige Petrus Canisius, $555-564$; quotations: 555,560 .

5 Acta Sanctae Sedis 30 (1897-1898): 3 .

6 Acta Apostolicae Sedis 17 (1925): 216, 349. 
urging German Catholics to take up his "combative spirit"? Pribilla rejected this interpretation, briefly rehearsing evidence for "the gentleness [Milde] and love that Canisius showed for Protestants." A clue to Pribilla's motivation for writing surfaces in the conclusion of his short article, when he pleaded "for the preservation of confessional peace and mutual understanding" between Catholics and Protestants. ${ }^{7}$ Pribilla, a Catholic pioneer in Christian ecumenism, consolidated this position in the first article of the September 1925 issue of Stimmen der Zeit, which discussed "the reunification in faith." Here he argued for mutual respect among Catholics and Protestants for the sake of the, albeit distant, goal of achieving Christian unity. ${ }^{8}$ Pribilla's defense of a gentle Canisius obviously competed with the official papal portrait.

Pribilla was not the only one to privilege a gentler and kinder Canisius as opposed to the papal interest in the militant Canisius. Johannes Janssen, "Germany's most influential Catholic historian" towards the end of nineteenth century, ${ }^{9}$ maintained that Canisius valued "Christian gentleness and kindness [Milde und Sanftmuth] as the best method for winning back Protestants" and that he abhorred "all harsh and rancorous polemic."10 Elaborating on Canisius's saintliness in Stimmen der Zeit in 1925, Peter Lippert, S.J. emphasized the love and respect that characterized Canisius's approach to his fellow human beings. These virtues allowed him to see the good in "his bitterest enemies" and to refrain from "the vicious tone of contemporary polemics" in both the Protestant and Catholic camps. ${ }^{11}$

The current Catholic commitment to ecumenism, now much more in evidence than in the 1920s, continues to drive the interpretation of a gentle and friendly Canisius. It seems anachronistic, however, to associate the sixteenthcentury Jesuit with a movement in Christianity that came into its own in the twentieth century. Nevertheless, long before the twentieth century, the desire

Max Pribilla, “Canisius und die Protestanten," Stimmen der Zeit 109 (1925): 396, 398, 400.

8 Max Pribilla, "Um die Wiedervereinigung im Glauben," Stimmen der Zeit 109 (1925): 401-415. On Pribilla, see Karl H. Neufeld, "Werk und Denken P. M. Pribillas S. I.," ARSI 44 (1975): 210, 217-21; and Neufeld, "Anfänge katholischer Ökumene: Max Pribilla (1874-1956)," Catholica 29 (1975): 1-19.

$9 \quad$ Neue Deutsche Biographie (Berlin: Duncker \& Humblot, 1953-), 10:343-44, at 343, s.v. "Janssen, Johannes" by Hubert Jedin.

10 Johannes Janssen, Geschichte des deutschen Volkes seit dem Ausgang des Mittelalters, vol. 4: Die politisch-kirchliche Revolution und ihre Bekämpfung seit dem sogenannten Augsburger Religionsfrieden vom Jahre 1555 bis zur Verkündigung der Concordienformel im Jahre 1580 (Freiburg im Breisgau: Herder, 1885), 382, 383.

11 Peter Lippert, "Petrus Canisius, der Heilige (Zu seiner Heiligsprechung 21. Mai 1925)," Stimmen der Zeit 109 (1925): 161-72, at 167 . 
for church unity has served as a sincere response to the consciousness of division. That desire manifested itself at the Council of Trent, even if at Trent, especially in 1552, Protestants and Catholics were unable to bridge deep ecclesiological differences. ${ }^{12}$ No doubt modern scholarship approaches Canisius from the vantage of a modern ecclesiological outlook. But while today's preoccupations can and do shape our grasp of yesterday's realities, to see Canisius through an ecumenical lens distorts historical vision. Such a distortion makes him more exceptional than he actually was.

Two relatively recent examples show how ecumenical commitments have influenced the interpretation of Canisius. In order to understand the motivations of Canisius and the Protestant praeceptorGermaniae PhilippMelanchthon, Julius Oswald, S.J. urged a thorough and critical investigation of historical circumstances. He also called for scholars "to withstand tensions and to overcome obstacles." This strategy alone would dismantle the "old adversarial stereotypes" that continue "to encumber ecumenical dialogue and to disturb interconfessional relationships." Oswald maintained that, "although he resolutely defended Catholicism, Canisius dealt with Protestants in a friendly way and made an effort to settle differences of opinion objectively."13 Four years before joining the Holy See's International Theological Commission (ITC) in 2004, Barbara Hallensleben held: "In his thought and actions, Canisius, in the obligatory commitment to the mission of Jesus Christ, remains oriented towards those who are outside." After quoting from an ITC document of 1996 that stated that Christ's truth was directed towards the service of humanity and that rejected any form of Christian proclamation that seeks to subdue its audience or control it "by means of an instrumental or strategic rationality," Hallensleben asked: "Should we also not esteem Peter Canisius a pioneering ecumenist?"14

We encounter the most sustained effort to assert Canisius's gentleness and love for Protestants in an essay that Johannes Metzler, S.J. published in $1927 \cdot{ }^{15}$

12 John W. O'Malley, Trent: What Happened at the Council (Cambridge: Harvard University Press, 2013), 149-56, 249.

13 Julius Oswald, "Ringen um die Einheit der Kirche: Petrus Canisius und Philipp Melanchthon," in Jesuitica: Forschungen zur frühen Geschichte des Jesuitenordens in Bayern bis zur Aufhebung 1773, ed. Oswald and Rita Haub (Munich: C. H. Beck, 2001), 20-40, at 20-21, 37.

14 Barbara Hallensleben, "Kirche in der Sendung. Die Antwort des Petrus Canisius auf die Erfahrung des 'draußen,' in Petrus Canisius SJ (1521-1597): Humanist und Europäer, ed. Rainer Berndt (Berlin: Akademie Verlag, 200o), 347-363, at 358, 363 .

15 Johannes Metzler, Der hl. Petrus Canisius und die Neuerer seiner Zeit (Münster: Aschendorffsche Verlagsbuchhandlung, 1927), 16, 28, 29, 39, 46 (references to Canisius's Milde); 3, 16, 32, 46 (references to Canisius's love of Protestants). 
At least rhetorically, Metzler's essay is not an exemplar of dispassionate objectivity. He celebrates Canisius as "a soldier of God [Gottesstreiter] of unconquerable strength" and as a "valiant soldier of God."16 Canisius's kindness towards his confessional opponents set him apart from the querulous age of the Reformation and proved his sanctity. Metzler did not take kindly to an assessment of the newly canonized saint that appeared in 1925 in the Catholic journal Hochland. Otto Karrer, a former Jesuit, implied that opportunism drove Canisius's recommendation of gentleness and maintained that he became more lenient over time. Metzler replied that Canisius evinced "sincere love from the beginning" and ended his essay with laudatory testimonials from Protestant commentators. ${ }^{17}$

Metzler's evidence is not consistently convincing. He presents Canisius as a welcome agent of conversion and as someone who encouraged prayer for Protestants to be freed from their errors and who patiently endured the tide of Protestant abuse that washed over him and the Society of Jesus. The evidence comes largely from Canisius's correspondence and should be taken seriously. Irrelevant, however, are the references to Canisius's support for Protestants who had converted to Catholicism since he supported them only as new Catholics. ${ }^{18}$ Metzler acknowledges Canisius's harsh views on Protestants and Protestantism but diffuses them by placing them within the context of the mentality of sixteenth-century Catholics and Protestants. Compared to "the coarse and bitter abuse of the religious reformers [Glaubensneurer]," Canisius's "sharpest statements" sound "extremely measured, and, yes, gentle." Metzler reaches for the tool of relativism again when he concedes that "a few times" Canisius applied "less than honorable epithets" to "Luther, Brenz, and other Reformers." Yet these "completely vanish" in the face of the "abuse" with which "these men honored pope and bishops, yes, even the Church Fathers and other saints."19 Conjuring away evidence by redirecting accusations at others is a less than honorable form of suppressing evidence.

In joining the debate about Peter Canisius and the Protestants to which Max Pribilla contributed in 1925, I seek to challenge the conventional wisdom about the Jesuit saint's Milde. The claim that Canisius was an extraordinarily irenic participant in the fierce confessional controversies of the sixteenth century must contend with evidence to the contrary. That evidence comes from sources

\footnotetext{
16 Ibid., 17,37 .

17 Ibid., 46-48, quotation: 47; Otto Karrer, "Petrus Canisius: Ein Charakterbild aus Anlaß seiner Heiligsprechung," Hochland 22 no. 2 (Apr.-Sept. 1925): 497-518, at 510, 505.

18 Metzler, Canisius, 22-24.

19 Ibid., 16, 37.
} 
that debaters have either ignored or used selectively. They like to cite a memorandum of 1583 in which Canisius advocates good will and affection towards Protestants without considering the elements of the memorandum that undermine this charitable approach. ${ }^{20}$ Assurances that Canisius's famous catechisms are free of spite do not withstand the scrutiny of these manuals, which were used throughout the early modern centuries to teach Catholics what to believe. To maintain that Canisius refrained from polemic or, more vaguely, from any "unnecessary polemic,"21 without considering the two weighty works that he published against the Lutheran Magdeburg Centuriators in particular but with all Protestants in mind is to overlook the most obvious sort of evidence. Popes Pius IX, Leo XIII, and Pius XI grasped a fundamental characteristic of Canisius that regularly surfaces in his writing. Much like his Catholic and Protestant counterparts in the Reformation era, he was a fighter for his faith and, as some Swiss Catholic admirers praised him at the end of his life, a "scourge of heretics."22 We may not with confidence herald Canisius as an ecumenist avant la lettre.

Although Canisius's invectives did not routinely indulge in vulgarity, they betrayed a combative spirit against Protestants and Protestantism, a spirit reflected more forthrightly in the praise of modern popes than in the pleas of his modern apologists. Canisius deliberately participated in, and did not avoid, the mêlée of bitter religious controversy conspicuous in the Reformation era. In principle, he was like most other controversialists of his day, Catholic and Protestant, and like most other controversialists he exhibited hostility more than gentleness.

\section{The Treatment of Heretics}

In August 1554, in a letter to Canisius, Ignatius of Loyola, founder of the Society of Jesus, proposed several ways of restoring Catholicism in the lands of Archduke Ferdinand of Austria. Canisius, then stationed in Vienna, should relay to Ferdinand whatever proposals prudence recommended. Ignatius's proposals can be divided into two categories: the elimination of heresy and the

\footnotetext{
$20 \quad$ Ibid., 18-19.

21 Hans-Peter Kolvenbach, "Canisius: 'ein Modell des ökumenischen Dialogs' (Johannes Paul II)," in Petrus Canisius: Zu seinem 40o. Todestag am 21. December 1997 (Würzburg: Office of the Vicar General of the Diocese of Würzburg, 1998), 111-24, at 112.

22 Otto Braunsberger, ed., Beati Petri Canisii Societatis Iesu epistulae et acta [hereafter PCEA], 8 vols. (Freiburg im Breisgau: Herder, 1896-1923), 8:447.
} 
promotion of Catholicism. Heresy should have no purchase on public life. Ferdinand should not tolerate heretics on his council or in provincial government. Professors at the University of Vienna should be demoted if they countenance anything opposed to the Catholic religion. All those involved in the instruction of youth in private colleges should lose their positions if they prove similarly lax in the defense of Catholicism. Heretical books should be burned or removed from Ferdinand's territories. ${ }^{23}$ "Preachers of heresies, propounders of heresy [haeresiarchae], and finally any people who have been caught infecting others with this plague should be punished with the most severe penalties" if they do not repent within a month and a day of a public warning. For the recalcitrant, Ignatius envisions various penalties: public shame, ineligibility for "all future honors, and if appropriate, exile, imprisonment, or in some cases even death." Ignatius quickly relents, however, when he says that he does not advocate the application of capital punishment or the establishment of the Inquisition, something that Germany in its present condition could not accept. ${ }^{24}$

A reply to Ignatius's advice has not survived in Canisius's published correspondence, but he obviously must have agreed with some of the proposals. On a visit to Nijmegen, his birthplace, in 1565 , he burned his relatives' nonCatholic books. His visit served as a catalyst for Catholics in Nijmegen to organize resistance against Protestants in the city. ${ }^{25} \mathrm{In}$ a long memorandum sent in 1583 to Claudio Acquaviva, the Society's superior general, Canisius recommended that the advisors and courtiers of bishops should only be Catholic. ${ }^{26}$

At Acquaviva's request, Canisius addressed three topics in the memorandum: the duty of Jesuits to communicate with their neighbors, their duty "to help heretics, especially the German ones," and the way in which the graduates of the German College, situated in Rome and administered by the Jesuits, could be more properly deserving of their fatherland as they return to it. In a discussion of eight "inconveniences" (incommoda), he listed what Jesuits should avoid when coming into contact with heretics. They should at an initial encounter refrain from confronting them harshly and treating them severely, for it was incumbent upon them "constantly to instruct them in a spirit of kindness inasmuch as we should reconcile their hearts to us in the Lord with

\footnotetext{
23 PCEA 1:489-90.

24 PCEA 1:491.

25 PCEA 5:664; Judith Pollmann, "Countering the Reformation in France and the Netherlands: Clerical Leadership and Catholic Violence 1550-1585," Past and Present 190 (2006): 83-120, at 106 .

26 PCEA 8:142.
} 
all affection and good will." Furthermore, Jesuits should not debate matters of faith with heretics, nor try to vanquish their pride, mention things that offend them, put too much energy into "excusing the abuses of the clergy," quarrel about "the true interpretation of Scripture," treat all heretics in the same way since they should be divided into leaders and followers, and reprove them for vices especially in evidence among Catholics. With seemingly well-intentioned condescension, Canisius explains that the many Germans who have attached themselves "to the new sectarians" have done so "out of ignorance more than malice." "They err," he continues "but without strife, without stubbornness and obstinacy" and, because they are "by nature simple and uncomplicated," they are "easily disposed to lap up what they, born and raised in the Lutheran heresy, have learned either in their schools, or in their places of worship, or in writings."27

If we were to be satisfied that Canisius's discussion of the incommoda presents incontestable evidence of his gentle spirit towards Protestants, we would be guilty of a simple and uncomplicated reading of his long memorandum. The bulk of the document does not consist of advice for "helping" German Protestants. Canisius's overriding concern is to rid Germany of heresy. His long series of recommendations include, among many other things, appropriate catechesis, the refutation of heretical books by Jesuit theologians, and the visitation and reform of German universities by authority of the pope. ${ }^{28}$

The good will that Canisius proposes does not replicate itself throughout the memorandum. The Germans are not simply a people who embrace new ideas without critical judgment. Later in the memorandum, they emerge as morally and spiritually incorrigible. Canisius portrays them as inveterate gluttons and drunkards incapable of devotion. ${ }^{29}$ The distinction he draws between leaders and followers is not consistently operative in the document, in which he tends to write indiscriminately about heretics. Obstinacy is their "peculiar characteristic." ${ }^{30}$ More ominously, they are in league with the devil. The church must endure "the scourge of heresy" thanks to Satan who "through Martin Luther and other servants of the same Satan has attacked and divided Europe." Three more times Canisius identifies heretics, without mentioning any Protestant Reformers, as Satan's servants. ${ }^{31}$ They are also "harpies" who "serve the synagogue of Antichrist." ${ }^{2}$

\footnotetext{
27 PCEA 8:130-31.

28 PCEA 8:131, 133, 144.

29 PCEA 8:139-40.

30 PCEA 8:129-30.

31 PCEA 8:136, 138, 143.

32 PCEA 8:145.
} 
Although in the memorandum, when dealing with heretics, he frequently applies a medical metaphor to Christ, fellow Jesuits, the pope, civil officials, parish priests, preachers, theologians, and graduates of the German College in Rome, ${ }^{33}$ Canisius also thinks in terms of combat. He incorrectly believed that Ignatius founded the Society of Jesus as a "new bulwark for the Church against heretics." ${ }^{34}$ Jesuits should be prepared to shed their blood in the fight against heretics. Very few graduates of the German College have made it their life's mission to return to Germany and "to fight boldly with the heretics of their fatherland, the most pernicious enemies of Christ and the Church." They should "fight with the sword of the Spirit against the most pernicious opponents and, like skilled physicians of the soul, help so many thousands in the Christian flock against lurking wolves." The goal of their preaching should be the "consolidation of the faith and the persecution of heretics." They go forth "to the harvest as laborers and into battle as soldiers" with the weapons of the priesthood "to help the Germans at this time and to absolve the heretics." 35 The combat is obviously a spiritual one, but Canisius does advocate force: "It would be helpful for the pope to devise a precise plan, perhaps in concert with the emperor, by which heretical canons, no matter how distinguished and aristocratic they might be, could be ejected [profligentur] from cathedral churches. Thus they would stop stirring up the most troublesome scandals that consequently infect and besmirch the entire clergy but that are also perceived to arouse and increase the greatest scourges of God's wrath against all of Germany." ${ }^{36}$ The verb that he uses for the forcible removal of Protestant cathedral canons, profligare, means to hurl to the ground, to crush, to conquer. Neutralizing their noxious effect on the clergy and on Germany justifies their expulsion.

The tension between love and healing, on the one hand, and disparagement, demonization, and combat, on the other, largely dissolves in Canisius's catechetical and polemical writings. If the memorandum represents a struggle in his mind between choosing help for or defiance of Protestants, the catechisms and the polemics show that he had already opted for defiance. Canisius's advice for dealing with heretics is not a consistent plea for gentleness; nor does it mark a change of course. He must have been able to see some value in affection and good will, but the battle against heretics attracted his attention more.

\footnotetext{
33 PCEA 8:129, 131, 139, 140, 142, 146, 148, 150.

34 PCEA 8:135. John W. O'Malley, The First Jesuits (Cambridge: Harvard University Press, 1993), 16, maintains that the Jesuits were not initially established to fight Protestantism.

35 PCEA 8:135, 147, 150, 151 .

36 PCEA 8:145.
} 


\section{Catechesis Against Heretics}

Religious polemics in the Reformation era typically found their way into catechisms and confessions of faith. Luther's Large Catechism (1529) mocked "Carthusian holiness." 37 In expounding the sixth commandment-the prohibition against adultery-Luther attacked "the papist mob, priests, monks, and nuns." In disparaging and forbidding marriage and vaunting their chastity, they "strive against God's ordinance and command." Nobody demonstrates so little respect and desire for chastity as those who renounce marriage "for greater holiness" and who "either openly and outrageously wallow in fornication or secretly engage in what is so much more repulsive that one dare not mention it."38 Johann Gropper's catechetical Handbook of Christian Instruction [Enchiridion christianae institutionis], first published in 1538 and soon widely acclaimed throughout Catholic Europe, rejected the "impious Anabaptists" and the "impious Sacramentarian heretics." ${ }^{39}$ In distinguishing between the Lord's Supper and the "papal Mass," the Heidelberg Catechism (1563) denounced the Mass as "an accursed form of idolatry" [ein vermaledetye Abgötterey]. ${ }^{40}$ When the Confession de foy (1559) of French Reformed Protestants described the invocation of the saints as "an abuse and deception of Satan," it was obviously attacking Catholicism. It also denounced the "diabolical fantasies" of the anti-Trinitarian Michael Servetus. The Second Helvetic Confession (1566) not only explicitly lashed out against Servetus; it also condemned Caspar Schwenkfeldt and the Anabaptists. ${ }^{41}$

Canisius was by no means the first Catholic catechist since Luther's break with Rome, but he was arguably the most influential in the sixteenth century, particularly in the Holy Roman Empire. His Large Catechism, the Summa doctrinae christianae, first appeared in 1555. Canisius published the so-called Smallest and Small Catechisms in 1556 and 1558, respectively. German translations quickly supplemented the Latin texts and eventually, before Canisius's death, his catechisms were available in several European languages.

37 D. Martin Luthers Werke: Kritische Gesamtausgabe, vol. 3o/1 (Weimar: Hermann Böhlaus Nachfolger, 1910), 149, 160.

38 Ibid., 162.

39 Canones concilii provincialis Coloniensis (Cologne: Quentel, 1538), LXXIV ${ }^{\mathrm{r}}, \mathrm{XCII}^{\mathrm{r}}$. On the popularity of Gropper's catechism, see Johannes Meier, “Das 'Enchiridion christianae institutionis' (1538) von Johannes Gropper: Geschichte seiner Entstehung, Verbreitung und Nachwirkung," Zeitschrift für Kirchengeschichte 86 (1975): 289-328.

40 Wilhelm Niesel, ed., Bekenntnisschriften und Kirchenordnungen der nach Gottes Wort reformierten Kirche, $3^{\text {rd }}$ ed. (Zollikon-Zürich: Evangelischer Verlag, 1938), 169. Ibid., 71, 69, 236, 263. 
Paul Begheyn, S.J. has counted 347 editions of Canisius's various catechisms for the period $1555^{-1597}$ and $83^{2}$ editions for the period $1598-2004 \cdot{ }^{42}$ For German Catholics to know their "Canisi" was to have learned their catechism. Joseph Lortz claimed: "Since 1555, German Catholicism was inconceivable without the "Canisi."'43

Canisius scholars have repeatedly underlined the moderation of Canisius's catechisms. Otto Braunsberger, S.J. maintained that the Summa lacked the "abusive statements" [Kraftausdrücke] against Catholics found in Luther's Large Catechism. "The exposition," he insisted, "is dispassionate, factual, dignified." ${ }^{44}$ For Burckhart Schneider, S.J. the catechisms were "positively uplifting and in no way polemical or aggressive." Canisius "does not refute but expounds, and consequently he shuns any kind of polemic and absolutely abstains from mentioning the names of the Reformers, such as Luther, Melanchthon, and Zwingli." ${ }^{45}$ More recently, Hubert Filser and Stephan Leimgruber have advanced the same, by now conventional, argument. ${ }^{46}$

The evidence for this argument is ambiguous, however. Canisius certainly does not mention any contemporary adversaries and is capable of calmly expounding controversial questions. In the Summa, he explains the invocation of the saints, denies the priesthood of all believers, asserts the existence of purgatory, and defends clerical celibacy without any reference to those who would oppose him. ${ }^{47}$ Yet the choice not to mention names cannot conceal flashes of orthodox wrath. Canisius condemns the "error of the iconoclasts

42 Paul Begheyn, "The Catechism (1555) of Peter Canisius, the Most Published Book by a Dutch Author in History," Quaerendo 36 (2006): 51-84, at 55, 59, 61. On Canisius's catechisms, see also Otto Braunsberger, Entstehung und erste Entwicklung der Katechismen des seligen Petrus Canisius aus der Gesellschaft Jesu (Freiburg im Breisgau: Herder, 1893); Paul Begheyn, Petrus Canisius en zijn catechismus: De geschiedenis van een bestseller (Nijmegen: Museum Het Valkhof, 2005).

43 Joseph Lortz, Die Reformation in Deutschland, 2 vols. (Freiburg im Breisgau: Herder, 1941), 2:149.

44 Braunsberger, Entstehung, 43.

45 Burckhart Schneider, "Der 'Katechismus' des Petrus Canisius," in Bücher der Entscheidung, ed. Wilhelm Sandfuchs (Würzburg: Echter, 1964), 89-99, at 97, 98.

46 Hubert Filser, "Glaubenskontinuität auf der Basis der kirchlichen Tradition," in Canisius: Der Große Katechismus - Summa doctrinae christianae (1555), ed. and trans. Hubert Filser and Stephan Leimgruber (Regensburg: Schnell und Steiner, 2003), 277; Stephan Leimgruber, "Petrus Canisius und die Ökumene," in ibid., 338.

47 Friedrich Streicher, ed., S. Petri Canisii doctoris ecclesiae catechismi latini et germanici, 2 vols. (Rome: Pontificia Universitas Gregoriana; Munich: Officina Salesiana, 1933-1936), 1:15-16, 39-40, 42, 47 . 
who clearly fail to distinguish between the effigies of the gods and the images of Christ and also of the saints." 48 While not mentioning the Anabaptists in his exposition of the sacrament of baptism, he briefly refers to the repetition of baptism as "absolutely execrable." ${ }^{49}$ Five topics dominate the teaching of the Eucharist in the Summa: the real presence of Christ, transubstantiation, the adoration of the sacrament, the sacrament's sacrificial nature, and the reception of the sacrament in one or two kinds. ${ }^{50}$ Canisius proceeds without emotion until he arrives at the final topic. After consolidating his argument that the laity should receive the Eucharist in only one kind with pronouncements from the Councils of Basel and Constance, he registers his surprise that some people "guided by the appearance of private piety" take a different position. "In this respect," he continues, "they conspire with the new despisers of the Church against the venerable authority of the entire Church." 51

Canisius took aim at the Protestant doctrine of justification by faith alone. In 1566 , he revised the Summa to add, among other changes, an "appendix on the fall and justification of man according to the thinking and teaching of the Council of Trent." In the thirteenth section, "against the empty confidence of the heretics," Canisius contends that while "it is necessary to believe that sins can neither be remitted nor have ever been remitted except freely by divine mercy on account of Christ, to anyone boasting of confidence in and assurance of the remission of his sins and finding peace in this alone it must not be said, however, that sins are to be forgiven or have been forgiven." This can happen "among heretics and schismatics" and is the case "in our day" as "this empty confidence, divorced of all piety, is preached very abrasively against the Catholic Church." 52

The Protestant antipathy towards the papacy provoked Canisius's anger. In a chapter on the precepts of the church, Canisius originally defined the church as all those who, governed by the apostle Peter and his successors, profess the faith and teaching of Christ. ${ }^{53}$ In 1566 , when he revised the Summa, Canisius retained this definition but supplemented it with a sustained criticism of "heretics and schismatics." They do not deserve to be called the church, a designation that they "falsely appropriate for themselves." They might seem to profess Christ's teaching, but they refuse to be counted among the pope's

\footnotetext{
48 Ibid., 1:16.

49 Ibid., 1:28.

50 Ibid., 1:31.

$5^{1} \quad$ Ibid., 1:35.

52 Ibid., 1:201.

53 Ibid., 1:20.
} 
flock. Those "who deny and attack" the papacy do not understand the "glorious promises" that Christ made to Peter. They "openly disturb the peace and sure order of the Church," which cannot be "properly governed" and cannot withstand the gates of hell without the pope's "superior authority." "Finally," Canisius charges, "they shamelessly disparage the Fathers and their synods and writings that agree on this distinguished characteristic of the Church, and indeed the harmonious voice of all of Christendom." 54

In the chapter on the precepts of the church, Canisius is keen on defending unwritten traditions to reinforce the church's authority. He asks: "How much have people today strayed from the dignity and authority of these traditions?" In a word, he responds: plurimum - very much. Serious errors have emerged "concerning the teaching on these apostolic and ecclesiastical traditions." "Most despise them," he continues, "others neglect or patently regard them no more than any other regulations of civil authorities, and they pretend these are human ordinances that one apparently is free to observe or discard, calling them, furthermore, adiaphora, things of little or of absolutely no value." Canisius affirms: "God's word refutes them." Instrumental too are the patristic protagonists of the Summa, whom Canisius gladly and frequently mentions by name. He especially mobilizes Origen and Augustine against anonymous contemporary Protestants. Origen wrote: "We must consider a heretic everyone who, while professing belief in Christ, when it comes to the truth of the Christian faith differs in belief from what the definition of the Church's tradition holds." Augustine claimed: "In those matters in which Scripture lays down no clear rule, the custom of God's people or the ordinances of the ancestors are to be taken as legally binding. And as with transgressors of divine laws so too must despisers of ecclesiastical customs be subject to restraint [coërcendi sunt]." Canisius's appeal to this passage from Augustine suggests an inclination to use force against heretics. The final advantage of the teaching on the precepts and traditions of the church is the distinction it affords between Catholics and heretics. Catholics "simply assent" to the church's teaching mediated though Scripture or "approved by the tradition of the Fathers." "B5 "But those who are called heretics," or, as Canisius wrote in 1566, "those who are heretics abandon this simplicity of faith and the proven judgment of venerable mother Church and of the holy Fathers, and they put too much faith in themselves or in those who have deserted the Church to the extent that not even when they have been admonished do they see reason."56

\footnotetext{
54 Ibid., 1:108-109.

55 Ibid., 1:19, 20.

$5^{6} \quad$ Ibid., 1:23-24, 114 .
} 
Canisius's remarks about contemporary miscreants, who can be no other than Protestants, become less scattered and more cohesive in light of his concept of Christian identity. The opening question of the Summa reads: "Who may be called a Christian?" Canisius replies:

Whoever professes the saving teaching of Jesus Christ, true God and man, in his Church. Consequently, whoever is truly Christian and firmly abides [acquiescit] in that very teaching of Christ condemns and completely curses [damnat et detestatur penitus] all forms of worship and sects, which are everywhere found outside the teaching and Church of Christ, such as the Jewish, Muslim, and heretical sects. ${ }^{57}$

The most recent German translation (2003) of the Summa seems to dilute the force of detestatur penitus by rendering the phrase as ganz und garverabscheut: a true Christian "completely loathes" the worship and associations of Jews, Muslims, and heretics. ${ }^{58}$ Yet Canisius calls for more than loathing. He wants Catholics to curse religious deviants. The first German translation of the Summa, published in 1556, translates detestatur penitus more faithfully as verfluecht gäntzlich: the true Christian "entirely curses" the adversaries whom Canisius identifies. ${ }^{59}$

Canisius also begins the Latin edition of the Small Catechism with the question of Christian identity. He asks: "Who may be called a Christian and moreover a Catholic?" The requirements are baptism, profession of Christ's saving teaching, and a refusal to belong to "sects and any opinions inimical to the Catholic Church." The language becomes more heated, however, in the twentieth question: "Who are absolutely outside the Church?" They are Jews, infidels, heretics, schismatics, and the excommunicated. They all do not belong to the church "and consequently they continue to have no share in the spiritual life and salvation besides, beholden to Satan and everlasting death unless they come to their senses." Canisius teaches that Catholics must avoid all of these, "but especially heretics and schismatics must be shunned and moreover cursed [fugiendi ac execrandi] no less than deadly types of plague."60

In some German editions of the Small Catechism, Canisius articulates a discrete question about how one should consider those who are excluded from the church. Canisius intensifies the sense of alienation by adding that they

\footnotetext{
$57 \quad$ Ibid., $1: 6$.

58 Filser and Leimgruber, Petrus Canisius: Der Große Katechismus, 80.

59 Peter Canisius, Frag und antwurt Christlicher leer in den haubtstucken ([Vienna: Michael Zimmermann], 1556), Biiv-Biir ${ }^{\text {. }}$

6o Catechismi 1:238, 242-243.
} 
"certainly are in the wrath of God." ${ }^{11}$ The appropriate Catholic reaction is more physical than spiritual. Catholics should flee and shun [schewen] or flee and expel [scheuchen] "like the harmful plague" especially heretics and schismatics. $^{62}$

The Smallest Catechism, first printed in Latin in 1556 and in German in 1556 or 1557 , defines in the first question a Christian simply as anyone "who professes the saving teaching of Jesus Christ, true God and true man, in his Church." A tenth question asks how one should regard those outside the church: Jews, pagans, Turks, heretics, and the excommunicated. They will have "neither forgiveness of sins, nor eternal life, nor resurrection of the flesh other than for damnation." 63

Since Canisius's apologists wish to contrast his catechism with the immoderate pitch of writings of the Reformation era, it is instructive to compare his teaching on Christian identity with that of the Heidelberg Catechism. After explaining why Christ is called "anointed," it proceeds to ask in the thirtysecond question: "But why are you called a Christian?" The good Reformed German Protestant answers: "Because I am through faith a member of Christ and also a partaker of his anointing so that I too may confess his name, present myself to him as a living sacrifice of gratitude, and fight against sin and the devil with a clear conscience in this life and reign with him afterwards in eternity over all creatures." ${ }^{64}$ The Heidelberg Catechism saw the Mass as abominable, but it did not insist on antagonism, apart from strife with sin and Satan, in its conception of a Christian. Teaching a sense of Christian identity that did not include the deliberate execration of the religious deviant was quite possible in the Reformation era. Such an option evidently did not appeal to Canisius in the Summa or the Latin Small Catechism. He did not mention any Protestants by name, but the references to "the new despisers of the Church" and to his own times clearly show that he had them in mind. His Catholic readers should have had no trouble in thinking of Protestants when they encountered heretics, schismatics, and sects in his catechisms.

\section{Polemics against Protestants}

Canisius participated directly in the doctrinal controversies of his day. In 1556 , he preached while the Imperial Diet was in session at Regensburg (1556-1557).

\footnotetext{
$61 \quad$ Ibid., 2:123.

62 Ibid., 2:34, 124.

63 Ibid., 2:213, 215; cf. ibid., 1:265, 266.

64 Niesel, Bekenntnisschriften, 157.
} 
His sermons strengthened the Catholics but aroused the intense hatred of the Protestants. Catholics petitioned Archduke Ferdinand of Austria, King of the Romans, and Duke Albert V of Bavaria to have Canisius, as he reported to Diego Laínez, then the vicar general of the Society of Jesus, "to fight to the finish against those pests with the sword of the Spirit, namely the Word of God." 65 The Diet of Regensburg determined that the next religious colloquy between Catholics and Protestants should take place in Worms later in $1557 .{ }^{66}$ Canisius was a leading Catholic participant in the debate with representatives of the Lutheran Augsburg Confession, divided into two factions led by Philipp Melanchthon and his implacable opponent Matthias Flacius Illyricus. Canisius went to Worms, accompanied by his confrère Nicolaus Goudanus, with the blessing of Pope Paul IV and at the request of Ferdinand. Protestants must have viewed his participation with consternation. Eberhard van der Thann, minister to the Protestant Elector Palatine, opposed the inclusion of Canisius among the Catholic party, denouncing him as a demagogue [Hetzhund] of the bishop of Augsburg. ${ }^{67}$ Laínez instructed Goudanus and Canisius to make the defense of Catholic doctrine their main aim. They should conduct their public and private discussions with the Protestants and with Catholics "with moderation and moral dignity," combining "acuity and solid teaching." The two Jesuits were to be on their guard against "the deceit and cunning of the heretics," but they were to show their adversaries affection and abstain from doing them any harm. Canisius pursued a strategy of "divide and conquer" by observing that the Protestant principle of sola Scriptura did not prevent doctrinal discord among Lutherans. Thus he went beyond his brief for defense to mount a clever counter-attack. ${ }^{68}$ His strategy exacerbated tensions among the Lutherans,

65 PCEA, 2:23.

66 Bundschuh, Das Wormser Religionsgespräch, 216. On the discussions at Regensburg about the convocation of a religious colloquy, see also Rolf Decot, "Religionsgespräch und Reichstag: Der Regensburger Reichstag von 1556/57 und das Problem der Religionsgespräche auf Reichstagen," in Rolf Decot, Luthers Reformation zwischen Theologie und Reichspolitik, ed. Hans Josef Schmitz (Frankfurt am Main: Otto Lembeck, 2007), 63-8o.

67 Rolf Decot, "Katholische Stände und Theologen auf den Reichsversammlungen 1555-1557 in kommunikationsgeschichtlicher Perspektive," in Decot, Luthers Reformation, 103-25, at 115 .

68 Bundschuh, Das Wormser Religionsgespräch, 261, 264, 455, 457. For an edition of Laínez's instructions for Goudanus and Canisius, see Paul Begheyn, "Nikolaas Goudanus en het Godsdienstgesprek van Worms in 1557," Archief voor de Geschiedenis van de Katholieke Kerk in Nederland 11 (1969): 12-53, at 37-43, esp. 39 (quotations). For the text of Canisius's interventions at the colloquy, see Friedrich Förner (Fredericus Fornerus), Historia hactenus sepulta, colloquii Wormatiensis (Ingolstadt: Gregor Haenlin, 1624), 39-42, 51-63. 
which in turn led to the demise of the Colloquy. Canisius's passion was evident when he defended Catholicism from Lutheran charges of superstition that were the product of "calumny and those profane innovations in language." 69

In 1572, Canisius published with a new preface a defense of the Council of Trent's doctrine of justification written by Andrés de Vega, a Spanish theologian who took part in the Council's deliberations on justification. After exposing the disagreements among Protestants on this doctrine, Canisius harangues Protestants collectively and individually for their brazen treatment of the Church Fathers. He questions the intelligence of "Luther and his entire synagogue" and denounces Protestant critics of the Fathers as "fault-finders" and "traitors." $70 \mathrm{He}$ attacks the impudence of one Lutheran theologian, Tilemann Heshusius, and the "barbaric and insulting words" that another, Johannes Bugenhagen, spewed forth at the Fathers. The Magdeburg Centuriators are "blasphemers" for rejecting St. Boniface. ${ }^{71}$

Canisius's most concerted contribution to Reformation polemics came in the form of two voluminous treatises against "the corrupters of the Word of God." The first treatise, on John the Baptist, appeared in 1571. Canisius published its much longer companion on the Virgin Mary in 1577. The two treatises appeared in tandem in a revised edition in 1583 . Canisius undertook this project in apologetics at the behest of Pope Pius V, who wanted a Catholic response to the new history of the church that the Lutheran Magdeburg Centuriators began publishing in 1559. Canisius self-consciously extended his defense of Catholic doctrine beyond the Centuriators to combat many other Protestant leaders. ${ }^{72}$

Alfonso Salmerón, a fellow Jesuit, congratulated Canisius on the publication of the first treatise. In 1572, he reported that he had read the book from start to finish to his heart's content. It "seems to breathe nothing other than my Peter Canisius, that is, a unique and wonderful piety, a deep learning, a careful reading of the Fathers, remarkable encounters [congressiones] with heretics, an authentic and orthodox interpretation of the Word of God." Of the many Catholic replies to the Centuriators, none could match Canisius's book in charm and usefulness. Most important, none was "more appropriate and also suited to persuading the adversaries." "For you treat their wounds with flattering words," Salmerón continued, "and you apply mild medicine." It was obvious

\footnotetext{
69 Bundschuh, Das Wormser Religionsgespräch, 264; Förner, Historia sepulta, 60.

70 PCEA $7: 71,73,80$.

$71 \quad$ PCEA 7:73, 74, 78 .

72 James Brodrick, Saint Peter Canisius (1935 repr., Chicago: Loyola Press, 1998), 679-85; Rieß, Canisius, 393.
} 
why Canisius refrained "from every semblance of reproach and from harsher language." He aimed "to teach more than to subdue, to heal rather than reopen wounds." ${ }^{33}$ The myth of Canisius's mildness clearly began in the sixteenth century.

The prefaces to both treatises contradict Salmerón's assessment of the first. They serve at least three mutual purposes. First, they reveal the driving force behind "the enemies of the Church." Heretics are deputies of the devil. Second, Canisius clearly announces that his objective, as any reader would expect, is to refute the heretics of his day. Third, in the prefaces, Canisius sets the aggressive tone that informs the entire treatises. Three prefaces deserve our attention: a long "advisory [praemonitio] about the new corruptions of the Word of God and the sects prowling about in this era" in the treatise on John the Baptist and a short preface proper to this treatise as well as the substantial preface to Canisius's Marian treatise.

After lamenting the terrible conditions of his world-the "scandalous errors," the attacks of "profane scoffers" on the church, the "perverse stupidity," and the "impious, sacrilegious, and seditious efforts" unleashed by "wily and bold teachers" against God's Word-at the beginning of the praemonitio Canisius identifies "the true cause of such treacherous and prowling license." That cause was Satan. He was, Canisius added in 1583 , the year in which he wrote the memorandum for Acquaviva, "the father of heretics" and "the prince of sects."74

To associate the devil with one's religious opponents was standard in the Reformation era. The Scottish Confession of Faith of 1560 distinguished between "the trew Kirk" and the "fylthie Synagoge" of Satan. ${ }^{75}$ Canisius made the same distinction in a letter to Ignatius of Loyola in 1550. In Germany, "treachery rules instead of faith, the synagogue of Satan instead of the Church, insolence instead of obedience. ${ }^{76}$ In 1567 , Heshusius expressed gratitude for the conversion to Lutheranism of the ex-Jesuit Englishman Edward Thorn, who, "thanks to Peter Canisius, was completely saturated in papistical errors." Heshusius's Gratiarum actio doubled as a relentless attack on the blasphemies and errors

73 PCEA 7:40-41.

74 Peter Canisius, Commentariorum de verbi Dei corruptelis liber primus in quo de sanctissimi praecursoris Domini Ioannis Baptistae historia evangelica cum adversus alios huius temporis sectarios, tum contra novos Ecclesiasticae historiae consarcinatores sive Centuriatores pertractatur (Dillingen: Sebaldus Mayer, 1571), $\mathrm{b}_{4}^{\mathrm{v}}, \mathrm{cr}^{\mathrm{r}}$; Canisius, Commentariorum de verbi Dei corruptelis tomi duo (Ingolstadt: David Sartorius, 1583), 1:a5 , a6r .

76 PCEA 1:319. 
of the Jesuits, "the sworn enemies of the truth." Thorn "perceived that the Jesuits and the other advocates of papal idolatry were the true slaves of Satan."77

In one passage in the praemonitio, Canisius melds Satan with the Antichrist. A "Satanic fury" propels those who have cut themselves off from the Catholic Church to profess new teachings. Satan employs his "satellites and servants" to extend "his cruel tyranny." Then, alluding to 2 Thessalonians 2:7, he reminds his readers that "the mystery of injustice" labors in all the children who prepare the way "of the true Antichrist." In the 1583 edition, he proceeds to equate the heresy and schism that afflict Christendom with "the vanguard [praeambulum] of the coming Antichrist and the cutting short of a world on the brink of extinction." Those who actively pave the way for Antichrist and the world's end are "the iconoclasts, the enemies of God, and the despisers of Church ceremonies." Canisius identifies these as "either the German Lutherans, the French Huguenots, the Savoyard Calvinists, the Swiss Zwinglians, or the Netherlandish Beggars [Gensiti Belgici]."78

Protestantism for Canisius was Satanism. In the first treatise against the Centuriators, he counters the inclination of Luther's followers to compare their "dear father" and "reverend teacher" with John the Baptist, the forerunner of Christ, by seeing Luther as a pioneer of Antichrist. While the former contributed to the building up of the church, the latter managed to unsettle it. Luther's deeds ensured that "this current Satanism, which we perceive as having congealed from the cesspool of almost all heresies, was imported fifty years ago and in almost all of Europe has brought to bear the most powerful forces in order to divide the Church, destabilize governments, and stir up unrest."79 In his Notae evangelicae (1591-1593), meditations for priests on the gospel readings appointed for Sundays and feast days, to the "new Satanism" and its attacks on monks Canisius opposes a renewed appreciation for monasticism. ${ }^{80}$

An angry rhetoric of reproach burns through Canisius's polemical treatises. He condemns Protestants as a whole and explicitly targets individual sixteenth-century Reformers, both deceased and living. Their most common crimes are blasphemy, impiety, ignorance, and even stupidity or insanity. That Canisius on occasion concedes a correct view to his opponents does not

77 Tilemann Heshusius, Gratiarum actio pro conversione Eduardi Thornei Angli, qui relicta blasphema secta Iesuitarum, vera confessione ad sanctam ecclesiam Iesu Christi filii Dei, sese aggregavit (Lauingen: Emanuel Saltzer, ${ }_{1567}$ ), Aiiiv ${ }^{\mathrm{v}} \mathrm{Di}^{\mathrm{r}}$, Eiiv .

78 Canisius, Commentariorum de verbi Dei corruptelis tomi duo $(1583), 1: b_{5}{ }^{\mathrm{r}}$.

79 Canisius, Commentariorum de verbi Dei corruptelis liber primus (1571), 180 ${ }^{\mathrm{r}}$.

$80 \quad$ Friedrich Streicher, ed., S. Petri Canisii doctoris ecclesiae Meditationes seu notae in evangelicas lectiones, 3 vols. (Munich: 1957-61), 3:142. 
diminish the relentless contempt that he expresses for them. He eagerly quotes from Luther to argue for the immaculate conception of Mary in the teeth of opposition from other Protestants, but this does not deter Canisius from later attacking him "as the savage enemy of the Church and the raging commander of the sectarians of our times" who also "declared upon the Church a heinous war against the cult and veneration of Mary." ${ }^{\prime 1} \mathrm{~A}$ comment from the preface to the Marian treatise resonates with the answer to the first question of the Summa doctrinae christianae. Canisius observes that "devout people rightly curse the blasphemous doctors, who also vehemently insult God and his Christ," and who have in recent years appeared in great numbers in Poland, Hungary [Pannonia], Germany, and France. In his first polemic, he describes the Protestant faithful, "our sectarians," as "a people without restraint," who take no pleasure in moderation and "revel in the pleasures of the flesh." They are "seduced by the sweet food of new teaching" and "ensnared by a solely justifying faith." Their addiction to the "new sects" manifests itself in the indulgence of every form of licentiousness and the eager embrace of all kinds of disgraceful behavior. Thanks to the suasion of the Reformers [novatores], "they shamefully abuse this arbitrary lifestyle for every extravagance." ${ }^{2}$ To concede that "Canisius occasionally castigates the religious and moral conditions" of Protestants is to miss his deep-seated revulsion at their constitutional deficiencies. $^{83}$

More often than Braunsberger seemed to allow, Canisius descended to the "churlishness" (Grobianismus) that Lortz deplored in Catholic polemics of the Reformation era in which "dogmatic intolerance became contaminated and debased by personal resentment." 84 Two comments from the preface to the De Maria virgine dehumanize Protestants. The "new enemies of Mary" not only deserve comparison "with the savage Turks and the treacherous Jews," but they also seem in some respects to surpass "the declared and raving enemies, not to say dogs, of Christianity." 85 Canisius also compares the enemies of Mary to pigs that grunt at and defile a "precious stone," and since a pig is "an obtuse and stupid animal, it delights more in filth and in a slough than in gold and pearls." 86

81 Canisius, De Maria virgine incomparabili, et Dei genetrice sacrosancta libri quinque (Ingolstadt: David Sartorius, 1577), 57, 606.

82 Canisius, Commentariorum de verbi Dei corruptelis liber primus (1571), $80^{r-v}$.

83 Metzler, Canisius, 27. Emphasis mine.

84 PCEA 8:596; Lortz, Die Reformation in Deutschland, 2:166.

85 Canisius, De Maria virgine incomparabili, $\mathrm{b}_{2}^{\mathrm{v}}$.

86 Ibid., a5 ${ }^{\mathrm{r}}$. 
Personal defamation occurs frequently enough in Canisius's polemics. He responds to "the madness and abuse" of Johannes Brenz (d. 1570) for his impiety towards Mary, which earned him a comparison to a "savage beast." 87 Brenz was also a "profane mocker not only of the ancient Church but also of the Lord's cross." He had a "lust for recrimination" and was "foul-mouthed" [maledicus]. ${ }^{88}$ Other Lutherans were also maledici: Heshusius, whose "blasphemous mentor" was Luther, Spangenberg (Johannes [d. 1550] or his son Cyriakus [d. 1604]?), Johannes Marbach (d. 1581), and Jacob Heerbrand (d. 160o), whom Canisius also denounced as a "blasphemous critic." 89

Luther was "the plague of Europe."90 The world should not forget that by his own assessment he was "a deplorable slave of the flesh," and we should remember that he was a "pig in heat" for saying that just as it was not in his power not to be a man, so it was not his right not to be without a woman. This wisdom was not heavenly, but "earthly, beastly [animalis], and diabolical." Undoubtedly Luther was "more lecherous" than Jovinian of the fourth century who, although a celibate, was called the "Epicurus of the Christians." Canisius thinks that the sectarians, in following the example of their leader (Luther), imitate and revere the most filthy Jupiter and Venus more than Christ and Mary. ${ }^{91}$ The contempt for Luther in the De Maria virgine reflects the growing Jesuit animosity towards Luther after the death of Ignatius in $1556 .^{92}$

Conrad Wolf Platz, a Lutheran preacher in the free imperial city of Biberach, afforded a reader's response to Canisius's polemical writing that differed markedly from that of Salmerón. As Canisius was completing his treatise on Mary, he received from the Frankfurt book fair Platz's recently published book Catholische Inquisition (1577). He soon realized that this was not at all a Catholic book and made Platz the target of an entire chapter. ${ }^{93}$ Canisius does not reveal that Platz had used, among a series of Catholic publications, his Small Catechism, printed in German in Dillingen in 1568, as documentary evidence for errors under the papacy. ${ }^{94}$ Platz noticed Canisius's attack on him. In 1580 , he published a sermon on the proper use of the word "Catholic," to which he appended a "Christian Greeting to Doctor Peter Canisius." He quoted from the first paragraph of Canisius's chapter and a marginal note on that paragraph,

$87 \quad$ Ibid., 465,466 .

88 Ibid., 423 .

89 Ibid., 37, 423, 609, 671 .

90 Canisius, Commentariorum de verbi Dei corruptelis tomi duo (1583), 105.

91 Canisius, De Maria virgine incomparabili, 188.

92 O'Malley, The First Jesuits, 279.

93 Canisius, De Maria virgine incomparabili, 734 .

94 Conrad Wolf Platz, Catholische Inquisition (Tübingen: Alexander Hock, 1577), 1, 80, 159. 
objecting to Canisius's punning criticism that he was a wolf lying in wait for Catholic sheep and to statements in which Canisius branded him "a blasphemer and common enemy" and described him as "shameless" and "rash." He resented being compared to Goliath, in Canisius's words "that bastard and uncircumcised Philistine, a blasphemous despiser of the Church."95 Platz could have also recalled other terms of abuse: ironic outbursts-"O powerful and invincible Achilles!" "O distinguished interpreter of Scripture!"- and references to "presumptuous Platz" [procax Platzius], who was an "unjust judge" and an "absurd author."96 "As you then curse, vilify, and persecute me," Platz assures Canisius, "so I will bless and sincerely pray for you." His prayer is to ask God to enlighten Canisius and his "idolatry" and lead and keep him in "the knowledge of his divine Word."97

Blessing and prayer immediately yield to scolding. Baptized Peter, Canisius should consider that his "papal worship fights against the Word of God" and that Jesus's remonstration with the apostle Peter applies to him: "Get away from me Satan; you are a stumbling block to me since you are intent not on what is divine, but human" (see Matthew 16:23). The name "Canisius" recalls the dogs (canes) that the Bible in many places identifies as "the wicked and false teachers." Platz issues a challenge: Canisius should abandon the falsification of the Bible, all falsely added books, and all human rules and doctrines in conflict with the Word of God, and he should accept the canonical Scriptures and devote himself to the New Testament. If he does this, he will realize that the "Roman Papal Church and the papal faith, of which you are a Goliathic defender, is in no way Catholic." ${ }^{m 8}$

Platz answered Canisius in kind. A reviled wolf rejected a papal dog. One wounded Goliath struck out at another. Platz's "Christian Greeting" held up a Protestant mirror to Canisius, reflecting the scurrilous polemic of a renowned Catholic writer who took the time and effort to attack a lesser Lutheran light. Platz the obscure exposed Canisius's animosity towards Protestants, an animosity typical of sixteenth-century Catholic controversialists yet still inconsistent with the gentleness towards Protestants that modern interpreters would ascribe to Canisius.

95 Conrad Wolf Platz, Was, und welche im grund der warheit, Catholisch seyen und genendt sollen werden. Ein Christliche Predig gehalten in des Heyligen Reichsstatt Biberach, Sampt Christlichem Gruß, an Doctorem Petrum Canisium (Tübingen: Alexander Hock, 1580), Fiiir; cf. Canisius, De Maria virgine incomparabili, 735 .

97 Platz, Was, und welche im grund der warheit, Fiiir.

98 Ibid., Fiiir ${ }^{\mathrm{r}}-$ Fiv $^{\mathrm{r}}$. 


\section{Conclusion: A Model of Ecumenical Dialogue?}

Canisius was devoted to the man who in Mainz in 1543 received him into the Society of Jesus as a novice as well as to his memory. This was another Peter: the Savoyard Pierre Favre (d. 1546), beatified in 1872 and canonized in 2013 by the Jesuit pope, Francis I. Along with Francis Xavier, Favre was the earliest companion of Ignatius at the University of Paris and recruit for the future Society of Jesus. ${ }^{99}$ In 1543 , Canisius, the fresh recruit and university student preferred to think of Favre as an "angel of God." He praised him as a learned theologian of great depth, as "a man of such shining and excellent virtues."100 More than fifty years later, Canisius still remembered "my Favre" as a priest of intense emotional devotion, who at the display of relics in the cathedral of Mainz "shed many tears from a burning heart," and who often wept at his daily celebration of Mass. Favre, Canisius noted, found it "extremely difficult to bring back Germany, which had lapsed in the faith, to union with the Roman Church."101

Favre developed his ideas of how to treat Protestants in accordance with his own affective spirituality. His method began with a sense of service: "anyone who wishes to be of service to the heretics of this age must see to it that he holds them in great affection and loves them in truth, casting out of his spirit all thoughts that tend to make his respect for them grow cold." One should find common ground with heretics and proceed from moral and spiritual correction to matters of faith. The effort to have them embrace humility, patience, and other virtues was an arduous one, impossible without God's help. ${ }^{102}$ The imperative of love, however, endured beyond any consideration of difficulty, as was evident in Favre's spiritual journal, the Memoriale, which did not come into print until the nineteenth century, but to which Canisius refers in his memorandum to Acquaviva to emphasize the need for Jesuits to pray to the saints. ${ }^{103}$ Favre records that on November 19,1541 he felt a "great devotion" to pray for eight individuals regardless of their failings: "the pope, the emperor, the King of France, the King of England, Luther, the Turk, Bucer, Philip Melanchthon." Since he felt they had been judged by many, there arose in him "a sort of holy compassion, coming forth with a good spirit."104

\footnotetext{
99 O'Malley, The First Jesuits, 29.

100 PCEA 1:76.

101 PCEA 8:416, 418.

102 Favre, 400-402, quotation at 400.

103 PCEA 8:121.

104 Favre, 502.
} 
Peter Canisius knew and respected Pierre Favre, but he was no Pierre Favre in his relationship towards Protestants. First and foremost, as he writes in the memorandum to Acquaviva, he wanted to put Jesuits who encountered Protestants in Germany and elsewhere on their guard against "the spirit that gravely troubled both Pierre Favre and other pious people-I refer to the spirit of fear and reticence [diffidentia], just as if they seemed to invest in vain their energy in helping heretics and to want, as they say, to whitewash the Ethiopian." ${ }^{105}$ In his Adages, Erasmus of Rotterdam explained that the proverb Aethiopem dealbas (I.iv.5o)—"you whitewash the Ethiopian"—will make sense when "something barely respectable [res parum honesta] is embellished with verbal polish, or when an obscure person [or a person unworthy of commendation: illaudatus] is praised, or when an ignorant person incapable of being taught [indocilis] receives an education."106 Canisius clearly thought that to help heretics, at least without sufficient boldness, defied logic. He thus eschewed the diffident spirit of Favre.

In September 1997, the year that marked the 40oth anniversary of the death of Peter Canisius, the Swiss Catholic bishops made their ad limina visit to Rome. Pope John Paul II addressed them formally in an allocution. Canisius, who died in Swiss Fribourg, would have enjoyed the pope's insistence on obedience to the church, ${ }^{107}$ but he would have been puzzled by the end of the speech when the pope recognized "the importance of the ecumenical movement" in Switzerland. "Continue," the pope urged, "the common prayer and dialogue with all of our Christian brothers while clearly taking into account the doctrinal and pastoral questions that have not yet been resolved as well as various sensitivities." From ecumenism the pope proceeded to Peter Canisius and praised his "teaching, his pedagogical sense, and his apostolic activity in service of the gospel" as sources of inspiration for today. John Paul II had not finished with the theme of ecumenism, however, as he made this unprecedented papal comment about Canisius: "He is also a model of ecumenical dialogue, respectful of persons, filled with friendly affection [charité cordiale], and anxious to witness to his faith in Christ and his love for the Church, united to the bishops and the successor of Peter." ${ }^{108}$ Hans-Peter Kolvenbach, the superior general of the Jesuits at the time, sought to make sense of this

\footnotetext{
105 PCEA 8:128.

106 Opera omnia Desiderii Erasmi Roterodami, II-1, ed. Maria Laetitia van Poll-van de Lisdonk, Margaret Mann Phillips, and Christopher Robinson (Amsterdam: North Holland, 1993), 448.

107 Acta Apostolicae Sedis 90 (1998): $5^{10 .}$

108 Ibid., 513.
} 
pronouncement by underlining that allegiance to the truth was integral to ecumenism. ${ }^{109}$

Canisius's devotion and witness to Catholic truth was incontestable, but to call him un modèle de dialogue oecuménique is tantamount to a whitewash. He was, as Benno von Bundschuh observed in his study of Colloquy of Worms, "an irreconcilable opponent" to any policy of religious dialogue. The church, not a religious colloquy, must settle doctrinal disputes, Canisius believed. ${ }^{110}$ Favre might have been a better choice for the title that John Paul II bestowed on Canisius.

Unlike Favre, Canisius cannot pray consistently with equanimity and unalloyed love for Protestants. In his personal confession of faith, first published in 1571, against rumors that he had become a Protestant, Canisius resolved: "I do not know Luther; Calvin I spit out; I pronounce anathema on all heretics." He felt that God did not wish him to show good will to those "who cannot be your friends because they are in open conflict with your Church." Yet in the next sentence, he asks forgiveness for those who "either do not know or refuse to know what they do because they are prevented in part by the sway of horrible Satan, in part by the delusion of false doctrine."111 Meditating in the Notae evangelicae on the man without the appropriate attire at the royal wedding banquet (Matthew 22: 11-12), Canisius lashes out against Protestants-those who "most delusively comfort themselves and others with faith alone and also with hope in God's mercy." They are "mindless beasts rather than Christians, who with the prodigal son feed their bellies with the husks of pigs." Their minds "drown in earthly pleasures," and they demonstrate "no desire for the banquets of the gospel and the wedding feast of heaven." Canisius does not get far into a prayer for a change of mind for those "who today without a wedding garment profess Christianity in mortal sin and often perish in their crimes" before turning against them. In vain do they boast of "the grace of God, the merits of Christ, and the righteousness of faith" as they neglect works of love. Canisius aims two passages from 1 Corinthians against them: Paul's statement that faith is nothing without love (13:2) and his warning: "If anyone does not love our Lord Jesus Christ, let him be accursed [sit anathema]" (16: 22). ${ }^{112}$ How can a Jesuit who without compunction hurls anathemas at Protestants be an exemplar or forerunner of ecumenism?

\footnotetext{
109 Kolvenbach, "Canisius," 120.

110 Bundschuh, Das Wormser Religionsgespräch, 213.

111 PCEA 6:745, 746.

112 Streicher, Meditationes, 2:279, 280.
} 
Canisius's attitude towards Protestants was complicated and inconsistent. He could advocate something like Favre's good will and even pray for Protestants. Yet he could not shake from his mind thoughts that diminished his respect for them. He regularly demonized them and taught fellow Catholics to reject and curse them. To the general congregation of the Society gathered in Rome in 1565 , he advised against attacking heretics by name or with hatred. ${ }^{113}$ In 1567 , Friedrich von Wirsberg, Bishop of Würzburg, received advice from Canisius about reforming the church in Germany and in Würzburg. Although the Jesuit seemed to favor a middle course between severity and inaction, he believed that, while a few sectarians would return to the Catholic Church, more would defect and support religious reformation. Concessions were futile. He warned the bishop against the conversion of Lutherans into Calvinists, "the sacrilegious and intolerable persecutors of Catholics." 114 In 1573, he wrote to Cardinal Tolomeo Gallio, secretary of state under Pope Gregory XIII, to indicate his opposition to a war against Protestants, "the enemies of the Church," and to urge that "the pope should seize every opportunity [...] to insinuate his good will and paternal affection into the hearts of Protestants."115 Later in the Notae evangelicae, Canisius maintained that "a war undertaken to protect true religion is much more praiseworthy than to strive for that sort of peace that separates and severs us from God, from God's Church, and from true religion."116 Canisius complained in 1579 to Superior General Everard Mercurian that the Jesuit controversialist Gregorio de Valencia had "gone beyond the boundaries of moderation appropriate for our theologians when he attacked a certain Lutheran called Heerbrand." Worryingly, Valencia might produce yet another attack on Heerbrand, whom Canisius described as "a thoroughly foulmouthed and disputatious enemy."117 This was of course the same Heerbrand whom Canisius had attacked only two years earlier in the De Maria virgine.

Max Pribilla conceded that one could find intrinsically harsh expressions against Protestants in Canisius's writings, but what he regarded as "the numerous proofs" of "generosity and love" do not diminish, excuse, or set aside the saint's vehemence and combative spirit. ${ }^{118}$ That spirit was the public face of

\footnotetext{
113 PCEA 5:80-81.

114 PCEA 5:410-11, 413.

115 PCEA 7:114. On Gallio, see Antonio Menniti Ippolito, "The Secretariat of State as the Pope's Special Ministry," trans. Domenico Sella, in Court and Politics in Papal Rome, 1492-1700, ed. Gianvittorio Signorotto and Maria Antonietta Visceglia (Cambridge: Cambridge University Press, 2002), 132-57, at 140-43.

116 Streicher, Meditationes, 1:320.

117 PECA 7:510.

118 Pribilla, “Canisius und die Protestanten," 398.
} 
Canisius the catechist and polemicist, a spirit that Pius IX, Leo XIII, and Pius XI had recognized more accurately than John Paul II. Pius IX beatified and Pius XI canonized a Jesuit who fought for Catholic truth against Protestant heretics, while many of Canisius's admirers within the Society of Jesus and without have attributed his sanctity to a moderation that, as it turns out, is far from stable owing to the saint's confessional hostility. A saint does not need to be a stranger to the world in which he lived in order to be a saint. We should not expect, anachronistically, all Catholic saints from the confessionally riven Reformation era to foreshadow the laudable efforts of modern ecumenism to replace hostility with dialogue among Christians. Sixteenth-century Catholicism was capacious enough to embrace a Peter Canisius and a Pierre Favre. 